\title{
Kernos
}

Revue internationale et pluridisciplinaire de religion grecque antique

29 | 2016

Varia

\section{The Sea in the Greek Imagination}

\section{Emma Aston}

\section{CpenEdition \\ Journals}

\section{Electronic version}

URL: http://journals.openedition.org/kernos/2448

DOI: $10.4000 /$ kernos. 2448

ISSN: 2034-7871

\section{Publisher}

Centre international d'étude de la religion grecque antique

\section{Printed version}

Date of publication: 1 October 2016

Number of pages: 467-469

ISSN: 0776-3824

Electronic reference

Emma Aston, «The Sea in the Greek Imagination», Kernos [Online], 29 | 2016, Online since 01 October 2016, connection on 17 November 2020. URL : http://journals.openedition.org/kernos/2448 ; DOI : https://doi.org/10.4000/kernos.2448

This text was automatically generated on 17 November 2020.

Kernos 


\title{
The Sea in the Greek Imagination
}

\author{
Emma Aston
}

\section{REFERENCES}

Marie-Claire BEAULIEU, The Sea in the Greek Imagination, Philadelphia, University of Pennsylvania Press, 2016. 1 vol. 15,7 × 23,5 cm, ix+267 p. ISBN : 978-0-8122-4765-7

1 'The sea is everywhere in the Greek landscape.' So opens Marie-Claire Beaulieu (M.C.B.)'s new study, and her discussion goes on to show that this geographical ubiquity is matched by a cultural and psychological one. By examining the place of the sea in the Greek imagination, she delivers insights into a broad swathe of ancient thought, belief, anxieties and customs. Her central contention is that the sea is a mediating space in Greek mythology' (p.16), and she proceeds to explore the manifestation of this theme with regard to six clusters of mythological material, which she terms case-studies.

2 Chapter 1, 'Hygra keleutha', investigates motifs of travelling over (and into, and out of) the sea and their connection with significant changes of state. Transformation is a key theme: the sea is associated with shape-shifting beings and is, likewise, able to bring about or facilitate change in those who journey on it - change from living to dead, mortal to immortal, and so on. This chapter picks up, in a sense, the most interesting part of the workmanlike Introduction: the assertion that real sea-travel and exploration were, among the Greeks, expressed through and often fused with mythical journeys. This establishes clearly that the mythical sea and the real sea did not, for the Greeks, occupy completely different registers of experience, that figures such as Odysseus, Herakles and others both shaped and reflected how real travellers saw themselves and their activities. This helps to explain the striking potency of marine imagery in articulating the most fundamental aspects of the human condition, a potency which the subsequent chapters pursue.

3 Chapters 2-5 have a strongly gendered focus, and essentially alternate between male and female. Chapter 2, 'Heroic Coming-of-Age and the Sea', pursues the theme of 
transition developed in Chapter 1, here with regard to a specific manifestation: stories in which heroes achieve not only personal maturity but also political maturity as leaders, with the sea once again instrumental in these processes. The focus on epinikian odes allows for some brief reflection on what specific myths meant for the specific communities for which the poems were composed; this is a departure from the general method of the book, in which M.C.B. marshals the diverse sources, both literary and visual, which relate to a myth or mythical theme, and treats them in combination. I shall say more about this approach below.

Chapter 3, 'The Floating Chest', discusses myths of female sea-crossings and their connection with marriage, sex and childbirth in particular. We are back with the male in Chapter 4, 'Dolphin riders', which explores the striking frequency of stories in which dolphins carry men and boys; the animals are shown to be emblematic of the sea's mediatory and boundary-crossing role, since they are poised between fish and landanimal and between sea and sky. Chapter 5, 'Leaps of Faith?', moves again to the female: sex and marriage are revealed once again as the driving forces behind female action in the stories, but the motif of a leap into the sea can sometimes facilitate a more ambitious transition, into immortality and the company of the gods.

Gods have of course featured frequently throughout, but it is in Chapter 6, 'Dionysus and the Sea', that the divine comes centre-stage. Dolphins return, too, with the story of the Tyrrhenian pirates and their transformation, in an image-rich discussion. The fate of the pirates is linked by the author with the theme of loss of control: transformation, the sea's fluidity, drunkenness, epiphany, hallucination, all these things interlock in the world of Dionysos. The god provides an excellent culmination and encapsulation of the book's themes.

M.C.B. presents her approach as 'a mixture of synchronic and diachronic approaches' (p. 18), though in fact the synchronic predominates; with the exception of Chapter 2, there is little detailed discussion of the social and historical contexts which shaped particular retellings of myths. To say this is not to criticise. Reading this book reminded me of the excitement of writing about a wide-ranging mythological topos: ${ }^{1}$ the excitement of connections, and of the interconnectedness of ancient thought. The book's great merit is in the striking new associations it brings to light; for example (and this is to select one instance from many), the discussion of the 'mythical hydrological network' on p. 26-32 provided fascinating insight into the sea's role as an agent of connection in its own right, permitting unexpected passage on both the horizontal and the vertical axis. M.C.B.'s book has the same effect. Consulting Trophonios' oracle at Lebadeia is supposed to have left a man unable to laugh; the link between katabasis and laughlessness she follows through Lykophron, Pomponius Mela and others, and the links are illuminating. As M.C.B. later remarks (p. 134-135), 'A careful analysis reveals remarkable consistency across stories which have seemingly little to do with one another' - it is in the revelation of such latent connections that her main strength lies.

7 It need hardly be said that a sensitive treatment of context is important in the study of ancient myths, and yet the part of the book in which this was attempted in most detail, chapter 2, was for me the only part which occasioned any dissatisfaction. The focus on epinikian verse actually seemed to me to highlight how much was not being said, and indeed could not be said while keeping the book within reasonable bounds. The discussion of each Ode, while interesting, raised countless questions about the individuals or group for which it was composed (the complexities of the Thessalian 
case, for example, would fill a volume in their own right!), questions which there was not space enough to answer. More successful, in my view, is the adroit demonstration, in the other chapters, of the special power of miscellany, of authors and artists conducting a long-range conversation, in mythological language, across large gulfs of time, space and genre.

If there is an aspect of context which I think could have been further developed in places, it concerns the causes of convergence. Readers of the book must be struck by the coherence of the themes it explores, despite the seeming jumble of the material. But in what, really, does such coherence consist? Are writers and vase-painters passing the sea-themes among each other? Or are all drawing upon a common store of folk belief and unwritten storytelling? A greater sense of transmission and adaptation (rather than simply of mélange) would at times have been desirable.

New connections are the source of the book's originality and value. Its core argument is not truly innovative; it has been recognised for some time that the sea was associated by the Greeks with transitions, as M.C.B. herself acknowledges on p. $13-16 .{ }^{2}$ Her scope is broad, but not, as she says, comprehensive; instead, she presents case studies. The term 'case studies' has become very popular because it abnegates any perilous claim of universality, but the approach can be problematic: there is the risk that the case studies are selected because they support a general argument which the author wishes to make, in which case their selectivity is a great drawback. But M.C.B. actually does herself a disservice in labelling her chapters thus: they are ambitious and wide-ranging, as well as profoundly interrelated and mutually supporting, and - with the exception of Chapter 2 - have none of the snap-shot nature which 'case studies' suggests. (Perhaps they would be better termed called 'themes'.) No single book can be comprehensive, of course, but this one certainly has no reason to hide behind apologetic or evasive terminology.

The book is very nicely presented and produced, with clear (though black-and-white) illustrations. There are some small peculiarities, such as a wavering between Greek and Latin spelling conventions for no good reason that I could discern: in one paragraph on p. 108 for example we have 'Nauplios' alongside 'Telephus'; most of the spellings seem to have Latin forms, and it is odd to find sporadic deviations. Similarly, occasional modern colons creep into the Greek (as on p. 51 and 72). But such points are very minor compared with the otherwise high quality of the writing and of the presentation.

11 To sum up, this is a book which covers ideas and themes already established in past scholarship but does so in such a way as to draw our attention to associations and articulations which have not previously been given the scrutiny they deserve. It arrives at a time when the role of geography and topography in myth is receiving some fresh attention, and will of course especially interest scholars and students working on ancient views of the natural environment. But in fact all those wishing to gain a deeper understanding of how Greeks thought about their own place in the world would be well advised to read it. 


\section{NOTES}

1. .As I did in Mixanthōpoi: Animal-Human Hybrid Deities in Greek Religion, Liège, 2011 (Kernos, suppl. 25).

2. .In a sense, major aspects of B.'s argument may be found in compact form in R. BUXTON, Imaginary Greece, Cambridge, 1994, p. 97-104.

\section{AUTHORS}

\section{EMMA ASTON}

University of Reading 